\title{
The role of the hydrological cycle on the temporal patterns of macroinvertebrate assemblages in an Andean foothill stream in Colombia
}

\author{
María I. RÍOS-PULGARÍN,,${ }^{1,2}$ Mario BARLETTA,${ }^{3}$ María C. ARANGO-JARAMILLO, ${ }^{1}$ \\ Néstor J. MANCERA-RODRÍGUEZ ${ }^{2 *}$
}

${ }^{1}$ Laboratory of Limnology, Research Group Limnology and Water Resources, Universidad Católica de Oriente, Sector 3 , Cr 46 No. 40B-50, Rionegro (Antioquia), Colombia; ${ }^{2}$ Department of Forestry Sciences, Universidad Nacional de Colombia, sede Medellín, Research group Ecology and Wildlife Conservation, Calle 59A No. 63-20, Bloque 20, oficina 211, Medellin, Colombia; ${ }^{3}$ Universidade Federal de Pernambuco, Department of Oceanography, Laboratory of Ecology and Management of Estuarine and Aquatics Ecosystems, 50740-550 Recife, Pernambuco, Brazil

*Corresponding author: njmancer@unal.edu.co

\begin{abstract}
The seasonal and interannual changes in the structure, composition and functional feeding groups of the macroinvertebrate assemblage of the Guarinó River, a torrential system located in the Colombian Andean foothills, were examined in relation to the physical and chemical environmental changes associated with the hydrological cycle and the El Niño-Niña/Southern Oscillation (ENSO) between 2007 and 2010. Benthic samples were collected at three sites in the lower sections of the river. A total of 127 taxa were collected in the study, with the total taxonomic richness per site ranging from 82 to 96 taxa and benthos density averaging $5.41 \mathrm{ind}$. $\mathrm{m}^{-2}$. The density showed a tendency to decrease in periods of maximum river level and flow, particularly during La Niña phenomena, and to increase in dry periods, especially in the third year (2009-2010) during El Niño phenomena. The presence and abundance of taxa, functional feeding groups and life habits were regulated by environmental parameters associated with hydrological variability, derived of ENSO phenomena, especially flow rate values. The assemblage showed high taxonomic and functional diversity, which is characteristic of ecosystems affected by recurrent hydrological disturbances, exhibiting differentiated responses based on adaptive strategies against the local hydrologic regime that allow fast recovery under conditions like ENSO phenomena. Such responses include composition changes according to adaptations to different hydrological scenarios, the predominance of generalist trophic guilds and taxa with plasticity in their habits and range of environmental tolerance.
\end{abstract}

Key words: Flow; climatic alterations; hydrological disturbance; functional feeding groups.

Received: March 2015. Accepted: November 2015.

\section{INTRODUCTION}

Aquatic macroinvertebrates play an important role in ecosystem processes. Energetically, aquatic food chains are based on autochthonous material generated by primary producers or allochthonous material from the surrounding terrestrial ecosystem. Macroinvertebrates are important for making this material available and moving this energy to different trophic levels of aquatic systems, linking basal resources (e.g., algae and detritus) and upper trophic levels such as fish (Allan, 1996; Ramírez and Gutierrez-Fonseca, 2014). Although their mobility is restricted, biological characteristics such as drift and flight (in adults) allows them to respond to disturbances through mechanisms such as external recruitment and moving among patches not affected by the disturbance (Winemiller et al., 2010). This behavior may ensure the local taxonomic persistence and recolonization.

According to Flecker and Feifarek (1994) and Jacobsen $(2005,2008)$, the macroinvertebrate assemblages in tropical rivers are conditioned mainly by the flow regime and hy- drological disturbance, which affect the stability of the substrate, the drift process and the availability of allochthonous resources, with drift being generally aseasonal (Ramirez and Pringle, 1998; Rodriguez-Barrios et al., 2007). In a Neotropical stream of the Bolivian Andes, Tomanova et al. (2006) and Tomanova (2007) concluded that macroinvertebrate communities respond according to the Habitat Templet Theory (Southwood, 1977; Townsend, 1989; Townsend and Hildrew, 1994), establishing a close relationship between environmental conditions of habitat and the biological traits (adaptations) of taxa that live in this habitat. In this context, the local organism's ability to withstand floods and droughts (temporal variability) depends on the tolerance of each taxa (adaptive traits) and the shelter availability within the channel (spatial variability).

Several studies highlight the determinant value of local habitat for the macroinvertebrate assemblage structure in systems with a high frequency of hydrologic disturbance. Melo and Froehlich (2001) observed that richness and taxonomic composition were strongly cor- 
related with stream size and the presence of fine sediments over rocks. Assemblage structure in these streams seems to be deterministic; however, the authors recognise that torrential events can induce changes in the structure and that these changes depend strongly on substrate stability (Biggs et al., 1999). Longo et al. (2010) also found that features such as extensive vegetation cover and habitat stability (low drag) promote the rapid recovery of communities after disturbances. Ríos-Touma et al. (2009) suggest that although allochthonous organic matter (litter) inputs (used as shelter or food) depend on growing or transitional periods, their retention depends not only on the magnitude and variability of the discharge but also on the geomorphology of the river. Hydrological disturbances are events that affect assemblages according to the afore mentioned habitat characteristics, which cause changes to relative taxonomic abundance and persistence (presence/absence), selectively decreasing certain taxa (Hendricks, 1995, Swanson et al., 1998; Lake, 2000, Wang et al., 2013). Likewise, ecosystem function can be altered, so that changes in the functional feeding groups (FFG) or life habit composition may also be used as indicators of ecosystem change and recovery after disturbances (Ramírez and Gutierrez-Fonseca, 2014). These harsh disturbances may provide a habitat template that favours low-diversity macroinvertebrate assemblages that are highly persistent over time (Collier, 2008).

In tropical streams, several studies have examined the influence of stream flow on the seasonal variations of invertebrate communities (Hynes, 1975; Dudgeon, 1993; Flecker and Feifarek, 1994; Cressa, 1998; Jacobsen and Encalada, 1998; Ramirez and Pringle 1998), and the importance of hydrological disturbance in tropical mountain streams has been suggested by Jacobsen (2005), Tomanova et al. (2006), Tomanova (2007) and RíosTouma et al. (2011). In Colombia, studies on macroinvertebrate assemblages focus on issues such as the taxonomic diversity and/or their role as indicators of water quality (Roldan, 1988; Álvarez, 2005; Álvarez et al., 2006). Additional important contributions have focused on the trophic structure (Gutiérrez, 2006; Chará et al., 2010; Rodríguez-Barrios et al., 2011; Ramírez and Gutierrez-Fonseca, 2014) or drift phenomena (Rodríguez-Barrios et al., 2007; Aguirre-Pabón et al., 2012). The studies of Blanco (2003) and Longo et al. (2010) were among the few whose goal was to understand the dynamics of macroinvertebrate communities in the Colombian Andes and its relationship with the hydrological cycle. Although in South America the regional hydrologic conditions are strongly influenced by the cyclic occurrence of Niño/Niña events, except the Blanco (2003) research, there are no studies on this topic and influence of climatic variations on freshwater ecosystems remain poorly studied.

In this context, the objectives of the study were: i) to characterise the temporal (seasonal and interannual) variability in benthic macroinvertebrate assemblage structures; and ii) to evaluate the relationships between temporal patterns of macroinvertebrate assemblage and environmental parameters during El Niño/La Niña-Southern Oscillation (ENSO) phenomena of the period 2007-2010. This allows a first approach to the macroinvertebrate responses of torrential streams in the Andean region to natural hydrological disturbance and is thus expected to contribute to further research about the patterns of response among different aquatic community components. For this reason, the sampling design and methods for assessing the environmental variables refer to the work of Ríos-Pulgarín et al. (2015).

\section{METHODS}

\section{Study site}

The Guarinó River is a third-order stream of the Magdalena river basin, located in the foothill of the Central mountain range of the Colombian Andes (Fig. 1). It has a wide valley, tropical rain forest conditions with a mean annual precipitation of over $3800 \mathrm{~mm}$ per year, mean annual temperatures of greater than $25^{\circ} \mathrm{C}$, between 60 and $80 \%$ humidity (Holdridge, 1982) and soils of volcanic origin (Borrero, 2010). The hydrological regime is bimodal and for the study period (August 2007-April 2010), had considerable high flows exceeding $50 \mathrm{~m}^{3} \mathrm{~s}^{-1}$. The main channel has a length of $98 \mathrm{~km}$ until its confluence on the Magdalena river and presents a fast transition between the high zone and the alluvial plain (the last $16 \mathrm{~km}$ ), with periodic flooding events (Ríos-Pulgarín et al., 2015). The study reach was $6 \mathrm{~km}$ on the alluvial plain (foothills).

\section{Sampling design}

According to sampling design of Ríos-Pulgarín et al. (2015), three sampling areas were located in the alluvial plain of the Guarinó River, between 293 and $375 \mathrm{~m}$ of altitude, separated by a distance of $2 \mathrm{~km}$ : area 1: Jardín (north $5^{\circ} 17^{\prime} 41,4^{\prime \prime}$ and west $74^{\circ} 52^{\prime} 25.2^{\prime \prime}$ ), area 2: Bocatoma acueducto (north $5^{\circ} 18^{\prime} 30.5^{\prime \prime}$ and west $74^{\circ} 51^{\prime}$ ' 31.0"), and area 3: Casanguillas (north $5^{\circ} 19^{\prime} 07.9^{\prime \prime}$ and west $74^{\circ} 49^{\prime} 37.7^{\prime \prime}$ ') (Figure 1). To establish the variance in the macroinvertebrate composition between years and seasons, these areas were considered replicas because they are homogeneous in their physical structure, such as slopes, margins dedicated to grazing and beds of sand, pebbles and some medium-sized rocks.

Samples of benthic macroinvertebrates were collected over three consecutive hydrological years (between August 2007 and April 2010). Four samples per year were taken on each area, two in the dry season (August and February) and two in the rainy season (October and April). These periods, with a clear bimodal pattern, were established according to 30 years of historical precipitation 
records from the Puente Victoria weather station, located in area 1, belonging to the Instituto de Hidrología, Meteorología y Estudios Ambientales de Colombia - IDEAM (2012) (Fig. 2a).

The methods descried by Ríos-Pulgarín et al. (2015) for obtaining physical and chemical samples were followed. In both areas and sampling periods, chemical variables of the water, namely dissolved oxygen $\left(\mathrm{mg} \mathrm{L}^{-1}\right)$, conductivity $\left(\mu \mathrm{s} \mathrm{cm}^{-2}\right), \mathrm{pH}$ and temperature $\left({ }^{\circ} \mathrm{C}\right)$, were measured in situ using Shott and Mettler Toledo Cells. Water samples were analyzed in the laboratory for turbidity and nutrients such as phosphorous and nitrogen (APHA, AWWA and WEF, 2005). Data on hydrologic variables, such as river flow $\left(\mathrm{m}^{3} \mathrm{~s}^{-1}\right)$ and rainfall $(\mathrm{mm})$, were supplied by IDEAM (weather station Puente Victoria) and ISAGEN S.A. E.S.P. (Energy Generating Company, www.isagen.com.co). Both the level and flow values obtained from IDEAM for area 1 were validated and adjusted through gauging (by the profile cross-section method and a current meter) conducted in each sampling site. Few differences were found in the data, so compar- isons were considered valid with regard to historical behavior.

Sea surface temperature was used as a criterion for the occurrence of Niña/Niño ENSO phenomena, according to an ONI (Oceanic Niño Index) report from NOAA-NCEP (2014) for the American Pacific, which was corroborated by a comparison of the monthly historical mean of rainfall and river flow in the basin (IDEAM, 2012), with respect to those observed in the sampling periods. During the study, extreme hydroclimatic conditions associated with El Niño-Niña/Southern Oscillation (ENSO) were defined for the period 2007-2008 (year 1) as a transition to the La Niña phenomenon (early phase), the period 2008-2009 (year 2) as a La Niña year and the period 2009-2010 (year 3 ) as an El Niño year (NOAA-NCEP, 2012 and 2014; IDEAM, 2012) (Ríos-Pulgarín et al. 2015).

Macroinvertebrate samples were collected in the same sites in which environmental variables were measured over $100 \mathrm{~m}^{2}$ on the riverbank, according to the methodology described by Roldán (1988), and Roldán and Ramírez (2008). The D-net method was used with a 35-cm diameter, $40-\mathrm{cm}$

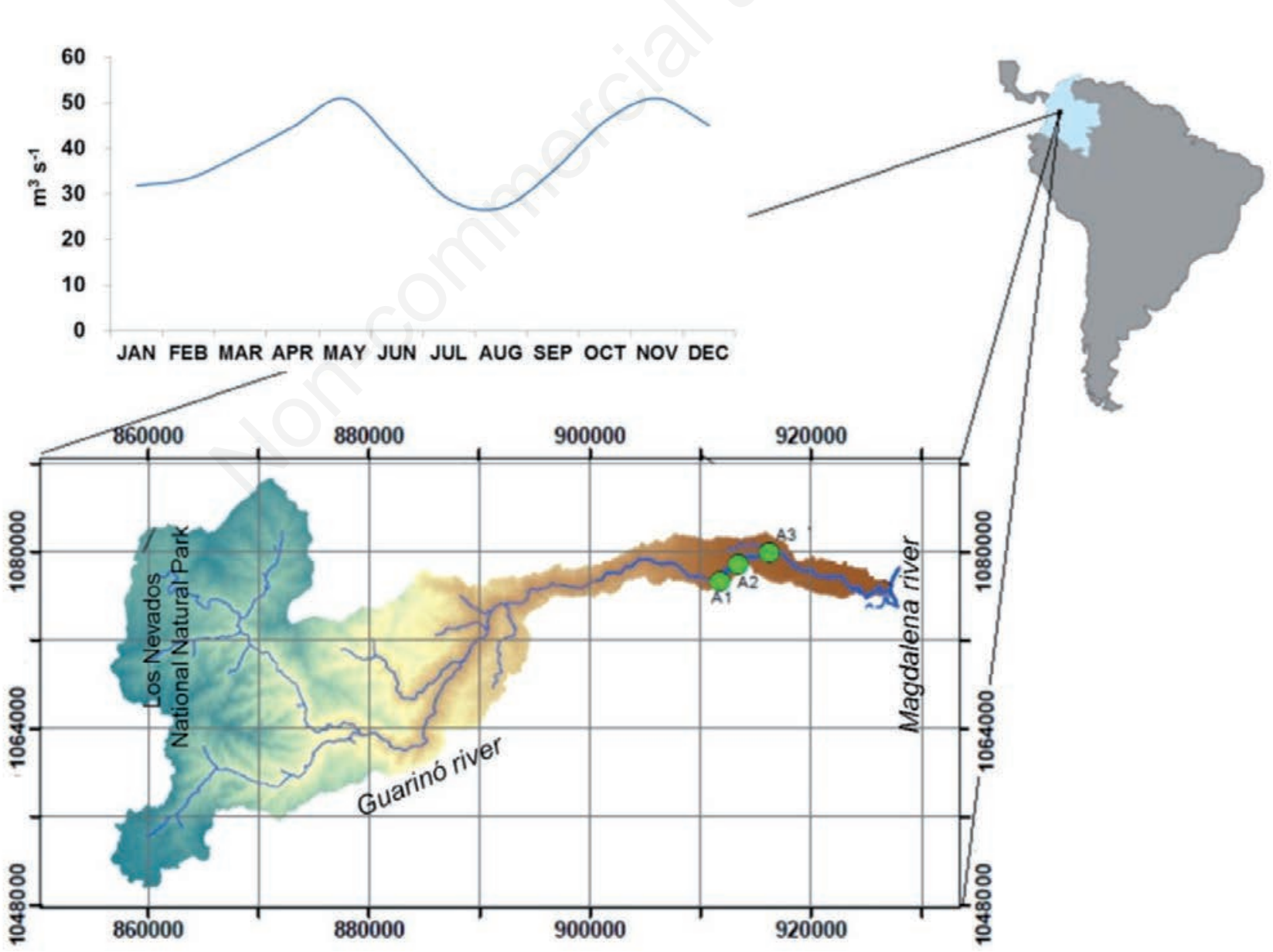

Fig. 1. The geographical location of the region of study and sampling stations (A1, Jardín; A2, Bocatoma acueducto; A3, Casanguillas) in the Guarinó River and average flow rate between 1980 and 2010. Source: Ríos-Pulgarín et al. (2015). 
depth, and a mesh of $500 \mu \mathrm{m}$, a screen mesh network of $500 \mu \mathrm{m}$ and manual collection on substrates (vegetation, submerged and semi-submerged wood debris, rocks, banks or deposition areas) were also applied. The samples were fixed and conserved in $70 \%$ alcohol. The identification of organisms was performed to the lowest taxonomic level possible using the keys of Edmonson (1959), Hungerford and Matsuda (1960), Edmunds (1976), Wiggins (1977), Correa (used 1980), McCafferty (1981), Álvarez (1982), Arango (1983), Bedoya (1984), Machado (1989), Domínguez and Peters (1992), Spangler and Santiago
(1992), Domínguez et al. (1994), Merritt and Cummins (1996), Aristizábal (2002), Posada and Roldán (2003) and Manzo (2005). The assignment of functional groups for most taxa was based on Merritt and Cummins (1996), Tomanova et al. (2006), Mathuriau et al. (2008), Chará et al. (2010), Rodríguez-Barrios et al. (2011) and Ramírez and Gutiérrez-Fonseca (2014). Studies on Neotropical rivers were preferred because the life histories of many taxa differ from their counterparts in temperate regions. Five categories of functional feeding groups (FFG) were established for macroinvertebrates of the Guarinó River: $\mathrm{CF}$

a ----Historical monthly mean $\longrightarrow 2007-2008 \longrightarrow 2008-2009-2009-2010$

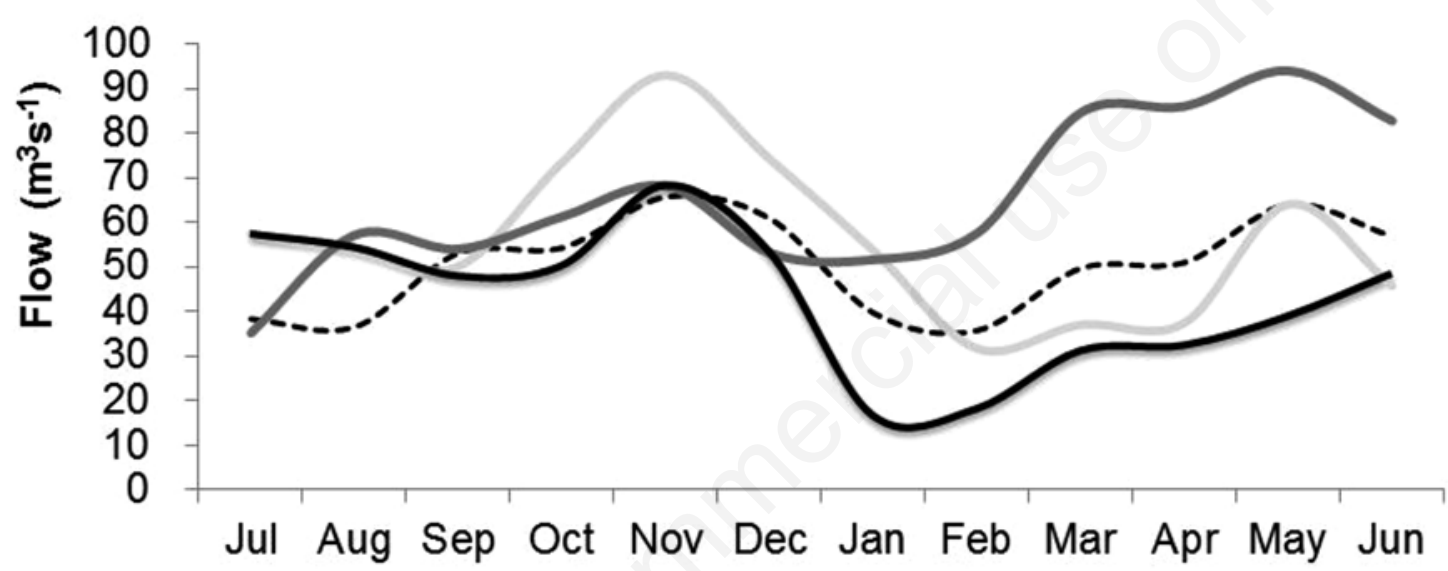

b

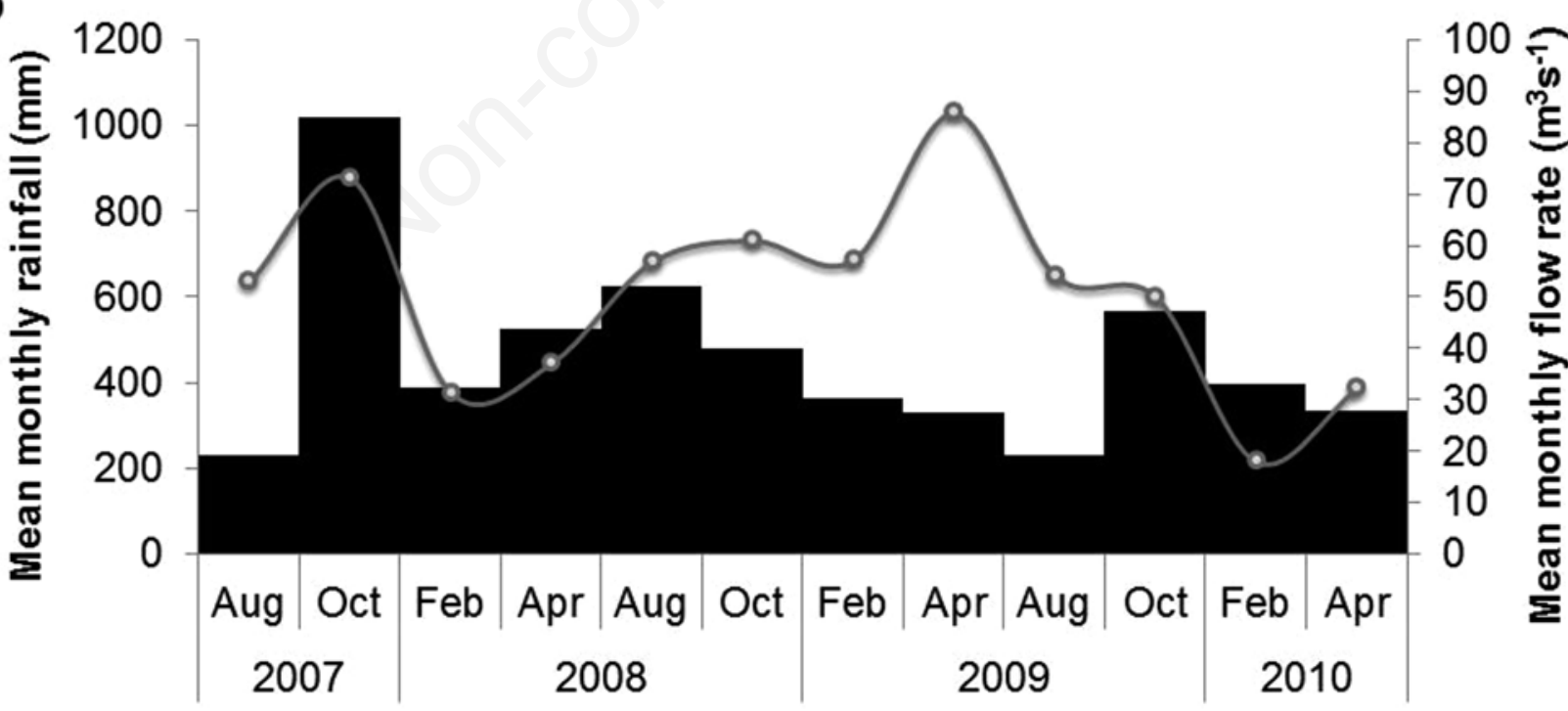

Mean monthly rainfall $\quad-0$-Mean monthly flow rate IDEAM

Fig. 2. The hydrological regime of the River Guarinó. a) Flow during the cycle 2007-2008 (year 1), 2008-2009 (year 2), and 2009-2010 (year 3) with respect to the average flow rate between 1980 and 2010. b) Average values of rainfall and flow between 2007 and 2010. Source: Ríos-Pulgarín et al. (2015). 
(collector-filterers), CG (collector-gatherers), SH (shredders), SC (scrapers) and PR (predators). Eight categories of life habit were established: $\mathrm{Bu}$ (burrowers), $\mathrm{Cb}$ (climbers), $\mathrm{Sp}$ (sprawlers), Sw (swimmers), Di (divers), Cg (clingers), $\mathrm{Cw}$ (crawlers) and $\mathrm{Sk}$ (skaters).

The number of individuals of each taxon was divided by the area of the sample, and the results were recorded as ind. $\mathrm{m}^{-2}$. The material collected was included within biological collections of the Laboratorio de limnología of the Universidad Católica de Oriente, Rionegro, Antioquia, Colombia; registered with cod CM-UCO.

\section{Data analysis}

To establish if there were temporary differences in the values of environmental variables, one-way analyses of variance (ANOVAs) were applied to each variable, which included different years and hydrological periods. Pairwise post-hoc comparisons were evaluated using the Tukey test to determine the particular levels of a factor that differ (Quinn and Keough, 2002).

Seasonal and interannual covariance analysis (ANCOVA) to evaluate the effect of the year, hydrological season and its interaction on the macroinvertebrate density and taxonomic richness was used. The variables year and season were considered as categorical variables, and river flow was considered a covariable, due to its high temporal variability and correlation with other environmental variables. Levene's Test for Homogeneity of Variance and Lilliefors (Kolmogorov-Smirnov) normality test were performed. The slope homogeneity of multiple regressions between each response variable and the river flow in each factor (year and season) was assessed.

Temporal patterns of taxonomic composition of the macroinvertebrate assemblages were examined with respect to environmental variables through canonical discriminant analysis, which was conducted on density data for the most frequent taxa, excluding those with a frequency of less than 5\% and an abundance of less than 3\% (Gauch, 1982; Blanco, 2003). In the CDA, taxa that help explain differences are represented as vectors whose length and direction is proportional to their contribution to explain the variability (Ríos-Pulgarín et al., 2015). Analyses of assemblage temporal variability were also applied on the different functional feeding groups (FFG) and life habits of macroinvertebrates, previously classified taxonomically and were complemented with canonical discriminant analysis. All analyses were conducted using R Software versions 2.15.2 (2012) and RWizar (Guisande, 2015).

\section{RESULTS}

\section{Environmental variables}

Rainfall and river flow conditions showed large interannual variations associated with ENSO and little sea- sonal variation, except during the first year (2007-2008), when the highest flow rates in October 2007 (La Niñaearly phase) were observed. The second year showed high and sustained rainfall and flow, whose effects on the Guarinó River extended to August 2009 (Y3D1) due to cumulative flows in the basin, whereas the third year showed sustained dry conditions (El Niño). Some physico-chemical characteristics of the water accompanied this variation during the third year, as increases in temperature (range 20 to $25^{\circ} \mathrm{C}$ ), $\mathrm{pH}$ (range 6.7 to 8.11 ), and conductivity (range 58.13 to $112 \mu \mathrm{Scm}^{-2}$ ) and reduction of dissolved oxygen (range 6 to $9.7 \mathrm{mg} \mathrm{L}^{-1}$ ). Nutrients and turbidity also declined in the third year, and their maximum values were recorded in October 2007. The values can be viewed in Tab. 1 and in Ríos-Pulgarín et al. (2015). In this study, significant differences $(\mathrm{P}<0.05)$ for all variables in year 3 (El Niño) were observed, whereas the values of turbidity, BOD, STT and nutrients differ in year 2 (La Niña). Significant correlations ( $\mathrm{P}<0.03$ for the Spearman correlation) between flow and other variables were found, except for BOD, alkalinity and $\mathrm{pH}$.

\section{Temporal variability in macroinvertebrate assemblages}

A total of 6498 individuals were captured, and 127 taxa of macroinvertebrates were identified. The most abundant orders were Diptera, Ephemeroptera and Trichoptera, particularly during dry periods and in year 3 (Fig. 3; Supplementary Tab. 1). Taxa Chironomidae morph 1, Camelobaetidius, Leptohyphes, Smicridea, Rhagovelia, Baetodes, Anacroneuria, Thraulodes, Heterelmis, Baetidae and Corydalus accounted for over $80 \%$ of the density and also frequencies greater than $50 \%$. Half of the assemblage was composed of rare taxa (less than $11 \%$ frequency of occurrence between samples).

Chironomidae morph 1, Anacroneura, Baetidae, Corydalus, Baetodes, Camelobaetidius and Smicridea showed increases in dry periods, especially the last three, which presented important increases in the third year (2009-2010). Whereas Leptohyphes, Huleeichus, Tricorythodes and Grumichella showed increases during the rains. Thraulodes and Rhagovelia showed no seasonal regularities (Fig. 4). The density showed a tendency to decrease in periods of maximum river levels, particularly during La Niña phenomena between April 2008 and April 2009 , and to increase in dry periods, especially during the El Niño year (2009-2010). The number of taxa showed no seasonal regularities, although they presented an increase in the third (El Niño) year (Fig. 4). The values of the covariate river flow were significantly related to changes in taxonomic richness between years (ANCOVA; $\mathrm{P}=0.003)$ but not with the hydrological periods $(\mathrm{P}=0.17)$. Significant differences in the number of taxa between year were observed $(\mathrm{P}=0.02)$, but no significant differences in 
density values between years or hydrological periods were found ( $\mathrm{P}=0.67$ and $\mathrm{P}=0.15$, respectively).

\section{Relationship between assemblage and environment}

The canonical analysis discriminant between years using the density and environmental data showed temporary variations in the assemblage related to interannual environmental gradients, separating the three years analyzed and representing $88.1 \%$ of the variance on the first canonical axis (Fig. 5). The taxa that made major contributions to the interannual variance were Leptohyphes, Macrelmis and Tricorythodes, which were associated with the highest values of nitrogen, turbidity and flow to discriminate the second year, whereas Nectopsyche, Leptonema, Simulium and Maruina were associated with dry periods with higher temperature and conductivity values in the first and third years.

\section{Functional variability}

In the Guarinó River, collector-gatherers and collector-filterers dominate in abundance throughout of this study $(40 \%)$, followed by scrapers and predators $(20 \%$ each). The largest richness corresponded to predators $(18 \%)$, scrapers $(13 \%)$ and taxa occupying two or more FFGs (13\%). Canonical discriminant analysis applied to Functional Feeding Groups (FFGs) showed interannual differences associated with hydrological variability, with an explained variance of $66 \%$ (Fig. 6). In the two first years, with higher river flow, oxygen, turbidity and nutrient values (La Niña), the FFG Collector-gatherers and shredders were more abundant. In the third year, corresponding to El Niño, most FFGs, especially collector-filterers, predators, scrapers and taxa with two or more categories had positive relationships with temperature, conductivity, hardness and pH. August 2009 (Dry 1/year 3), a transition period between El Niño and La Niña, showed some differences from the pattern observed for the other periods studied, such as increasing CG-CF (collector-gatherer-filterers) taxa, which can take their food from both sediment (CG) and suspended particles (CF), whereas predators (PR) and collectors-gatherers (CG) showed reductions (Fig. 7). Taxa with two or more habits or FFGs were dominant in number over three years and were relatively stable in their contributions.

The clinger habit represented between $35 \%$ and $49 \%$ of abundance annually. Canonical discriminant analysis applied to life habit revealed changes associated with hydrological variability, with an explained variance of $83.3 \%$ (Fig. 7). Swimmers and sprawlers were associated with periods of high river flow and high oxygen, turbidity and nutrient values (La Niña) but not with a drought period (year 3), which was dominated by burrower, skater, climber and clinger habits. As seen with GGFs, habits also

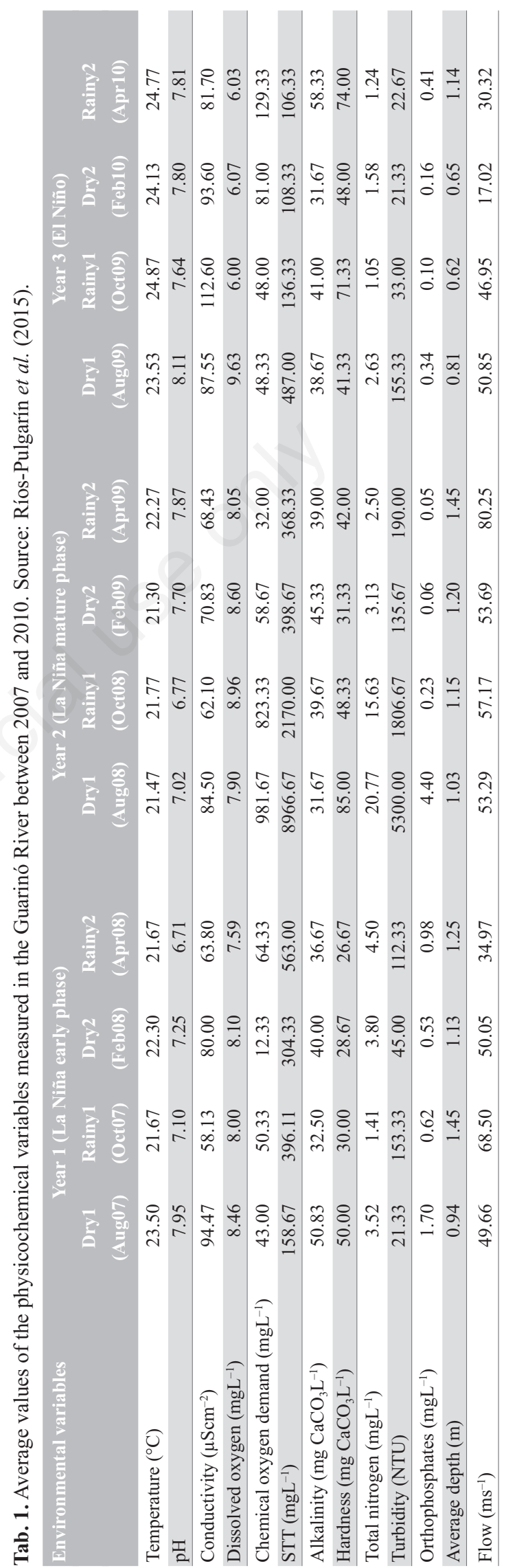




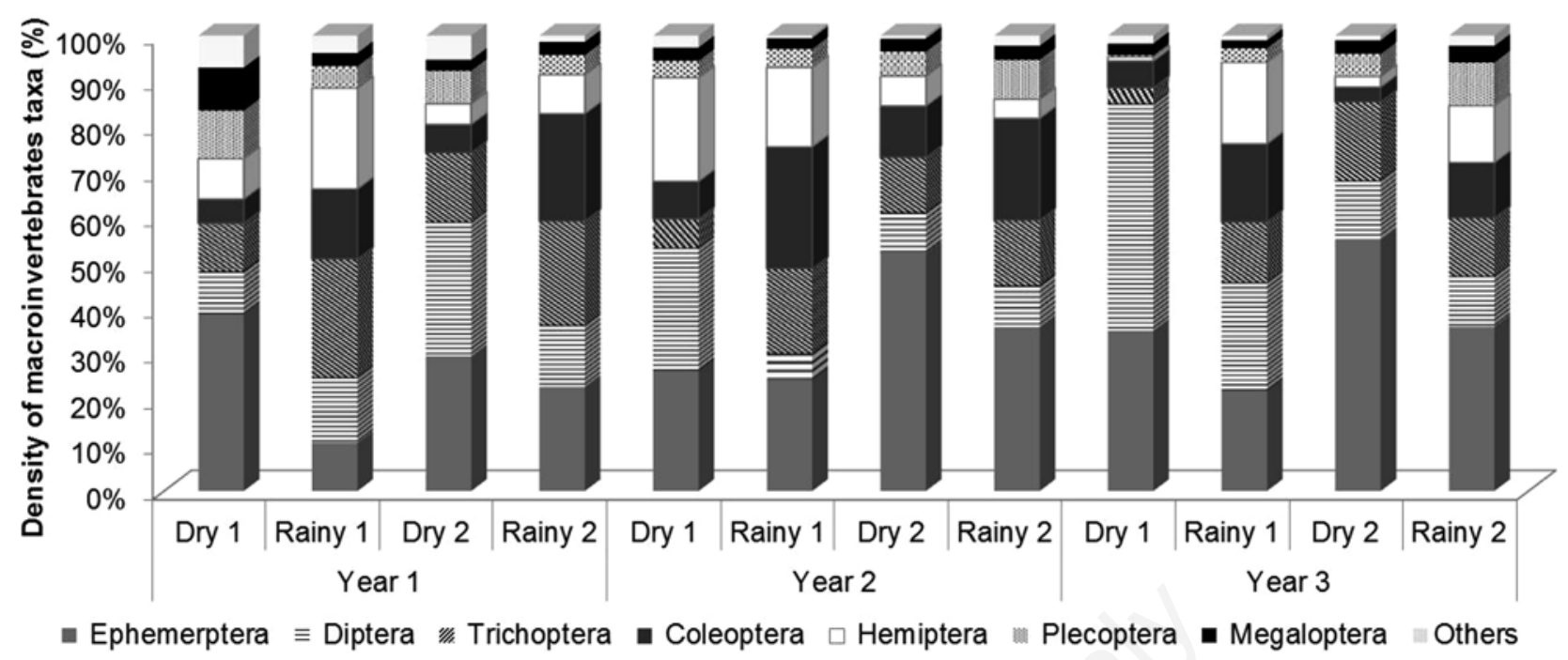

Fig. 3. The relative abundance of macroinvertebrate orders in the Guarinó River between 2007 and 2010.
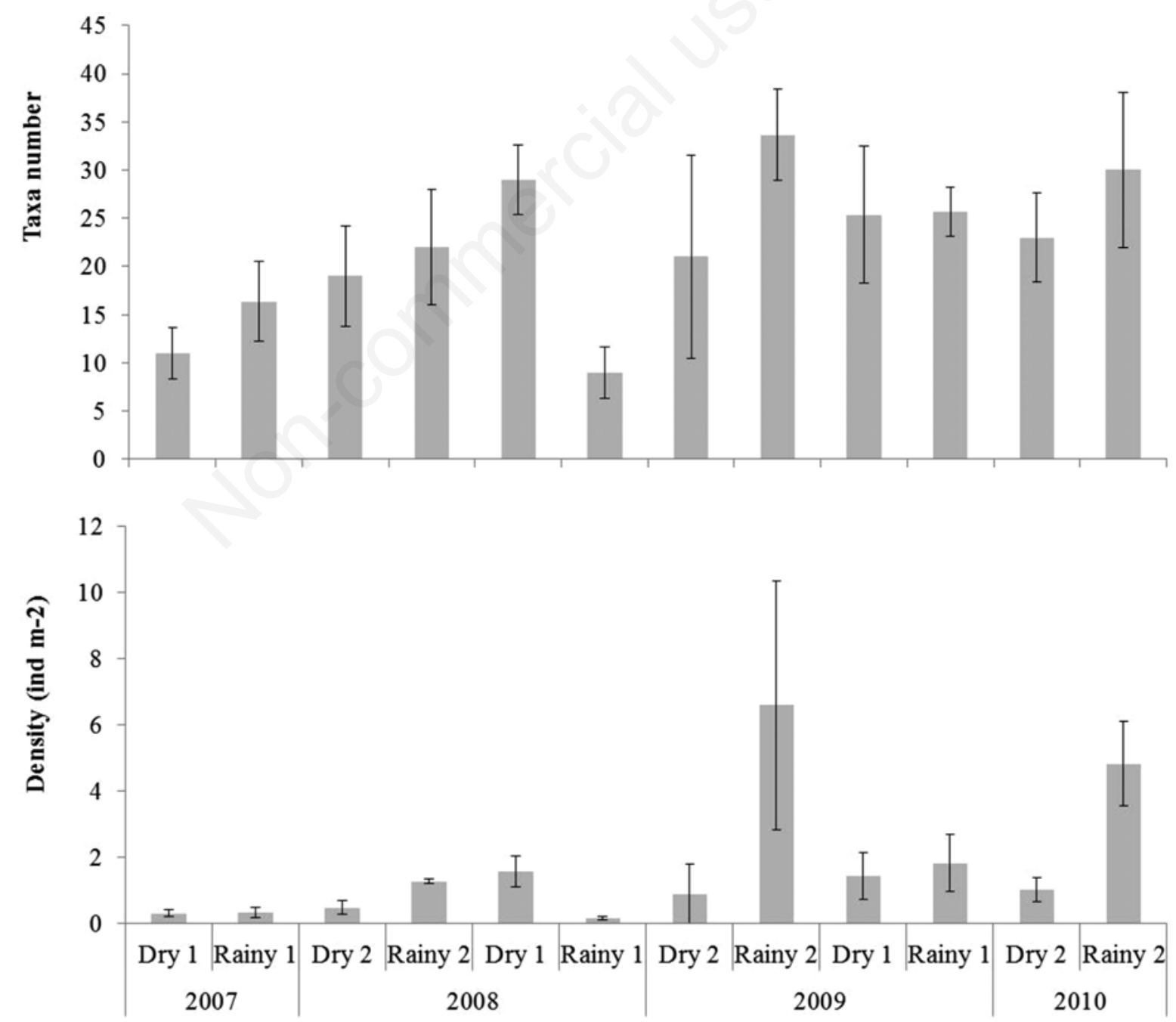

Fig. 4. Macroinvertebrate richness and density by hydrological period in the Guarinó River between 2007 and 2010. 
showed differences in the La Niña/El Niño transitional period (August 2009), with increases in burrowers and crawler-sprawlers as well as decreases in clinger habits.

\section{DISCUSSION}

In the Guarinó River, the period 2007-2010 has evident effects of the climatic extremes of the El NiñoNiña/Southern Oscillation (ENSO) phenomena, associated with substantial variability in flow, temperature and water chemistry (turbidity, nitrogen, dissolved oxygen). This coincides with findings by Molles and Dahm (1990), Scarsbrook et al. (2003) and Blanco et al. (2003).

The annual differences in physical variables affect Guarinó River water chemical variables: high values of turbidity and nutrients were associated with high flow periods in the second year (La Niña), when there were major drags in the upper basin and deposits generated clogging on rocky substrates (Ríos-Pulgarín et al., 2015). This phenomenon is associated with basin geomorphology (volcanic soils), land use (grazing) and recurrent torrential flows, which make them easily erodible and confirm the locally differential effects of ENSO.

According to Biggs et al. (2005), this environmental variability can affect communities through of stochastic processes (ecological disturbance) involving alterations in position, availability and quality of microhabitats that alter the structure of the assemblage. In the Guarinó River, a remarkable richness of Diptera at all hydrological periods, and to a lesser extent Odonata, Trichoptera, Ephemeroptera, Hemiptera and Coleoptera, evidenced the resistance of certain taxa of these groups to the alteration of water flow and habitats. However, the taxonomic composition of macroinvertebrate assemblages is sensitive to hydrological changes between contrasting moments. The increased density of Ephemeroptera, Trichoptera and Diptera during the dry season has been a general pattern in Colombia (Posada et al., 2000; Mathuriau et al., 2008, Longo et al., 2010), Ecuador (Jacobsen and Encalada, 1998) and Perú (Tomanova and Usseglio-Polatera, 2007). By contrast, Melo and Froehlich (2001) reported a similar community structure between the rainy and dry seasons in 10 Brazilian streams of a different order. Mathuriau et al. (2008) attributed this result to the difficulty in detecting faunal variations in regional-scale studies. Smicridea (Trichoptera) reaches its maximum density during El Niño because, despite its limited ability to swim, it is favoured by dry conditions due to its construction of net spinners on rock surfaces (Amaya, 2008), which counteract the effects of flow rate and improve the capture of a variety of organisms. Huleechius and Macrelmis (Coleoptera) predominated in periods of rain through spe-

Canonical scores

\section{Structure}

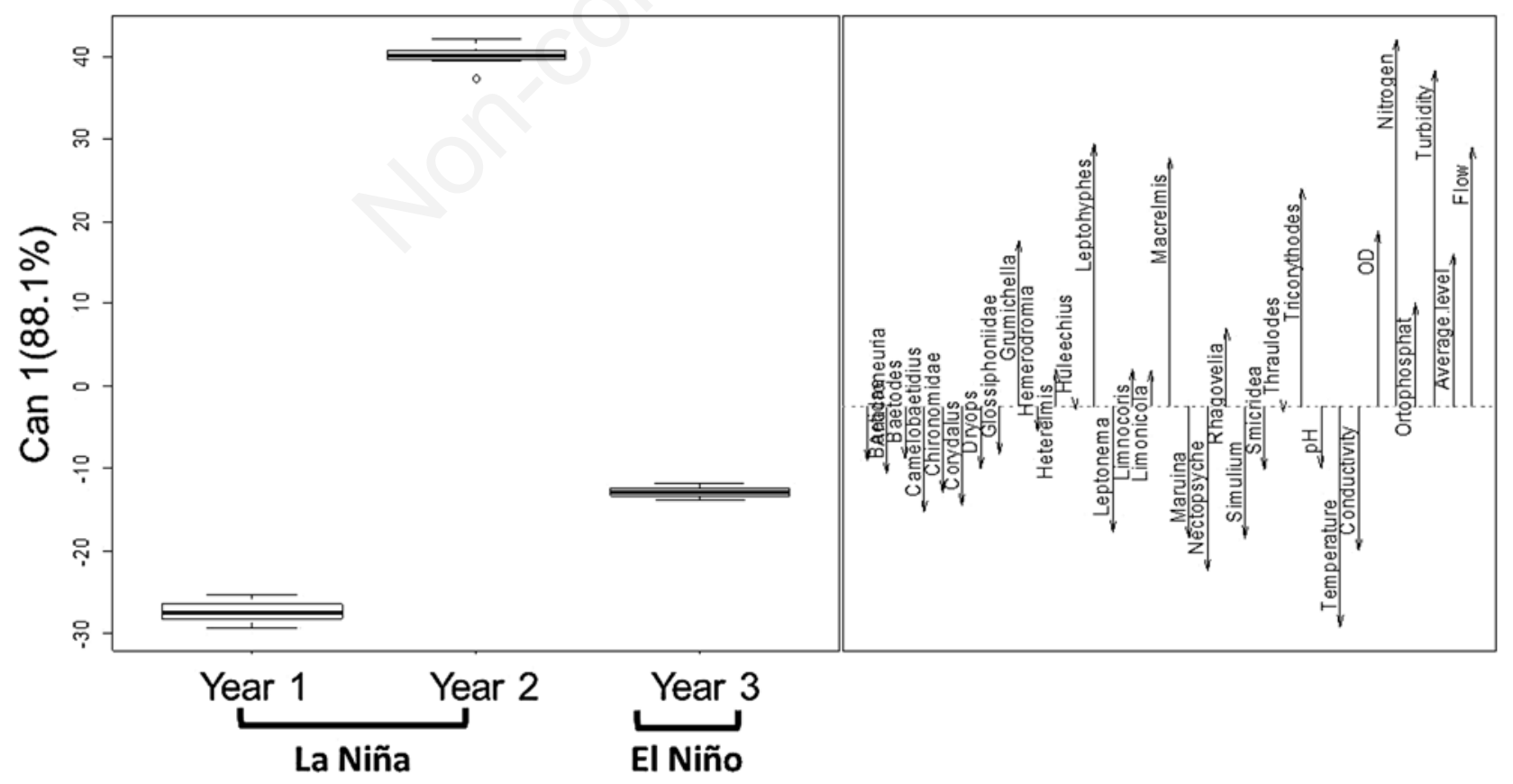

Fig. 5. Canonical discriminant analysis between years based on macroinvertebrate density and environmental variables of the Guarinó River between 2007 and 2010. 
cial adaptations that reduce friction, favouring their persistence in flood conditions where other groups are easily removed, which agrees with the results found by Brown, 1981. By contrast, Nectopsyche (Trichoptera) are most abundant in slow patches that can act as shelters, as found by Rios-Touma et al. (2011). Thraulodes (Ephemeroptra), a good swimmer, was found in both fast and slow water, in agreement with findings by White (2003) for the period of La Niña. Ragovelia (Hemiptera) has been captured in large quantities in both periods, drought or during rain in marginal pools, coinciding with those reported by Mazzucconi et al., 2009. This variability in the presence/ab- sence of taxa is evidence of water flow control on the occupation of habitats of benthic communities.

Despite its decline during the rains, Camelobaetidius and Baetodes (Ephemeroptera) can persist in both stations through morphological adaptations that allow high flow resistance and adhesion to the substrate with their tarsal claws and the dorsoventrally flattened form (hydrodynamic body), which makes it easier for them to settle in the flow layer located near the bottom of the river and use it as a refuge when the flow speeds are high, as found by Castro and Donato (2008). This phenomenon may encourage rapid recolonization when water levels decrease. Chi-

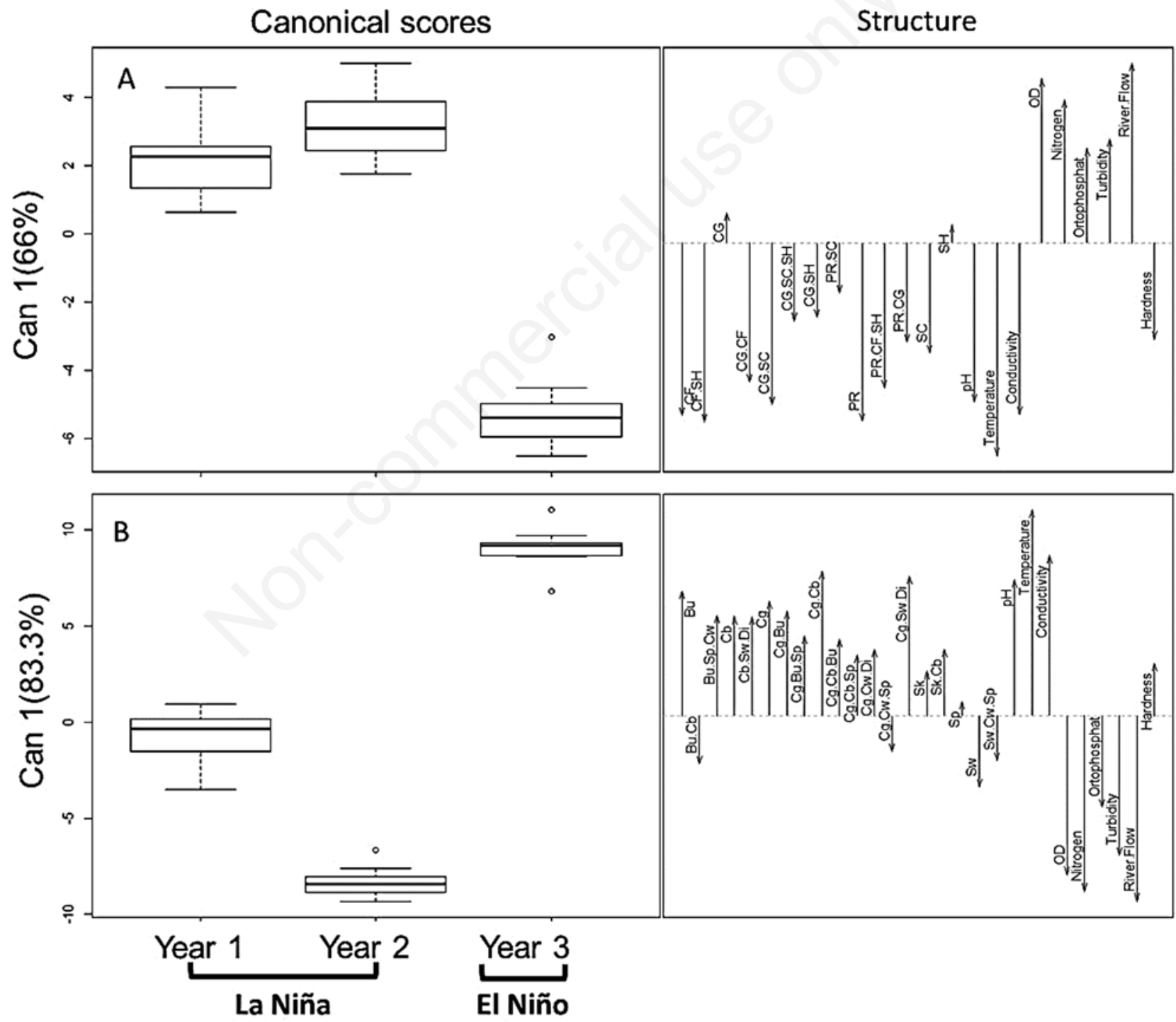

Fig. 6. Canonical discriminant analysis between years based on A) Functional Feeding Groups; and B) life habits of Guarinó River macroinvertebrates during the ENSO events that occurred between 2007 and 2010. CG, collectors-gatherers; CF, collectors-filterers; SH, shredders; SC, scrapers; PR, predators; Bu, Burrowers; Cb, climbers; Sp, sprawlers; Sw, swimmers; Di, divers; Cg, clingers; Cw, crawlers; Sk, skaters. 
ronomids and Simulium (Diptera), the most tolerant to flow range variability (Cobo and Gonzalez, 1990), were dominant in all hydrological periods. Like Blanco (2003) who examined a fifth-order river in the Valley of Cauca (Colombia), at Guarinó, we found that Simulium was equally abundant in both Niño/Niña periods. This is likely related to their high tolerance for low oxygen concentrations and capacity to exploit different food sources (Alvarez, 2005) and the fact that their larvae can change their location by drifting downstream on a silken thread, or by looping over the substrate surface using the posterior circlet and the hooks on the anterior proleg to retain a hold on secreted silk. Additionally, this group has more than one generation per year, unlike mayflies, caddisflies, stoneflies, moths and dragonflies, which appear only at certain times (Roldán and Ramirez, 2008). High richness and abundance the macroinvertebrates in the driest periods, particularly during the climatic extremes of the third year (El Niño phenomenon), showed the dependence of an assemblage on discharge and thus under the indirect control of rainfall, consistent with previous studies by Ramírez and Pringle, (1998), Jacobsen and Encalada (1998), Tomanova and Usseglio-Polatera (2007), Mathuriau et al. (2008) and Ríos-Touma et al. (2011). However, the greatest macroinvertebrate abundance in periods of drought as in the Guarino River has no general pattern in other rivers, as found by Castro and Donato (2008) in the rivers of Boyaca (eastern Andes of Colombia) and Ribeiro and Uieda (2005) in Brazilian rivers. According to those authors, the diversity of macroinvertebrates de-

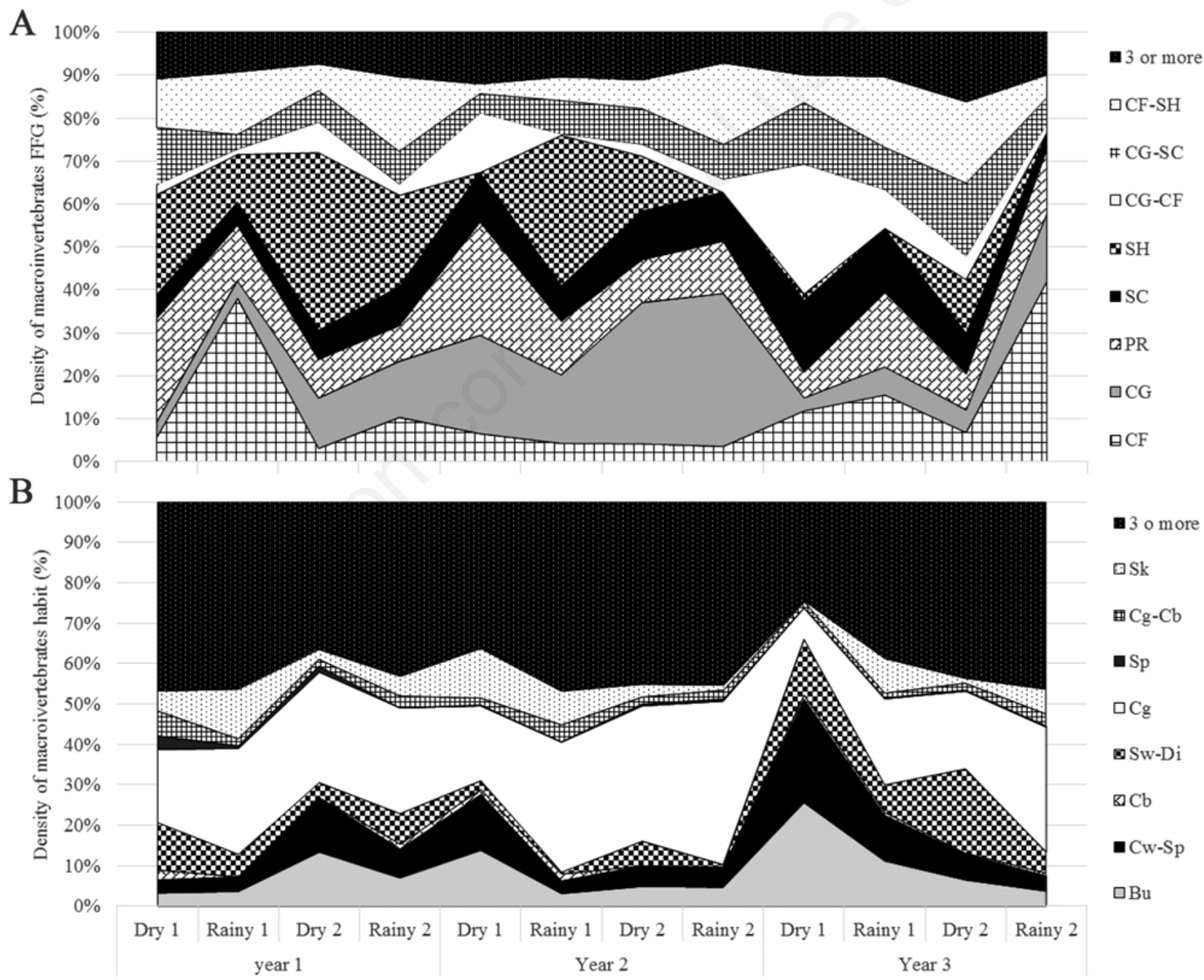

Fig. 7. A) The proportions of density for Functional Feeding Groups, and B) density for life habits of Guarinó River macroinvertebrates between 2007 and 2010. CG, collectors-gatherers; CF, collectors-filterers; SH, shredders; SC, scrapers; PR, predators; Bu, Burrowers; $\mathrm{Cb}$, climbers; Sp, sprawlers; Sw, swimmers; Di, divers; Cg, clingers; Cw, crawlers; Sk, skaters. 
creases during extreme drought with heavy rain conditions but increases during periods of transition. This contrasts with the results of Longo et al. (2010) from a secondary river of the Colombian Andean, where the adverse effects of drought periods on the macroinvertebrate diversity and abundance have been reported.

Local or regional differences in benthic assemblage responses are also seen in terms of abundance. High abundance during El Niño in the Guarinó River was related to more stable hydrological conditions, the food supply for macroinvertebrates and both depth and flow drag lows, which contribute to create a favourable habitat for organisms, contrary to what occurred during La Niña. Floods, during the wet phase of the ENSO phenomenon (La Niña), have been shown to reduce the number of benthic invertebrates in New México (Molles and Dahm, 1990) and west of the Colombian Andes (Blanco, 2003), given that the rates of post-flood recovery by stream communities appear to be dependent on local flood frequency. Alternately, in Canada, droughts act as a disturbance mechanism that simplifies benthos assemblages (Gilbert et al., 2008). On a local scale, Blanco (2003) found that both the diversity and density decrease during the La Niña phenomenon (wet phase of ENSO) but with differences between high and low stream gradients.

These results suggest an important effect of local conditions (hydrologic and habitat) on community responses to hydrological disturbances and suppose that there does not appear to be a general pattern in the Andean rivers. Therefore, the results cannot be extrapolated to all Andean streams. Firmer conclusions in this regard require verification that all studies used adequate methods for capturing macroinvertebrates of all habitats in the current, using appropriate sampling equipment and with the same intensity. Sampling bias or errors in taxonomic identification could have resulted in an abundance and taxon richness value underestimation, which does not allow us to compare these data with results from other studies. The rapid increase in the number of organisms in the dry period after La Niña in the Guarinó River suggests that succession is a mechanism of resilience to hydrological disturbance, similar to that found in studies of Grimm and Fisher (1989), Boulton et al. (2013) and Blanchette and Pearson (2012) in arid ecosystems of Arizona and Australia, subject to seasonal flooding. These studies have documented that macroinvertebrate recolonisation occurs quickly after the floods recede and in a stochastic manner, as adaptive response to disturbance. However, in these dry areas, environmental stability periods between the two disorders are long in relation to the life cycle of organisms, whereas in the Guarinó River, they are shorter.

In functional terms, in the Guarinó River, predators, scrapers and taxa occupying two or more FFGs showed the greatest richness, whereas collectors, scrapers and predators showed the greatest abundance. Ramirez and Pringle (1998), Blanco (2003) and Tomanova et al. (2006) found similar results. However, in all of these studies, predators and shredders were found to be poorly represented because of limited food resources. According to Tomanova et al. (2006), the feeding strategies of scrapers, predators and shredders involve greater mobility (active search for food) or the occupation of unstable substrates (shredders on litter) and, therefore, greater exposure to currents. So, these strategies may be suitable for invertebrates living in environments with frequent hydrological disturbance by flood, but the relatively high diversity of predators and organisms occupying various FFGs in the Guarinó River also suggests that an exhaustive and extended sampling results in highly representative samples. In fact, low diversity (taxonomic and functional) in others streams may also be due to richness underestimation associated with sampling methods, such as the use of an exclusively surber net for capture and short time series.

The observed interannual differences in the functional composition in the Guarinó River, with significant increases in all groups during El Niño (ENSO phenomena 2007-2010), is in agreement with the results of Blanco (2003) for the ENSO phenomena 1997-1999. The diversity and abundance of FFGs decreased considerably during La Niña, which can be explained by the negative effect of water velocity on filterers or availability of litter for shredders. It was further found that the greater abundance of collector-gatherers during high water, collectorfilterers during the dry season and taxa that have both gatherer and filterer FFGs (GC-CF) increased in the La Niña-El Niño transition (disturbance conditions). For example, Leptonema and Smicridea (Hydropsychidae), which build nets in fast flowing habitats and filter drifting material (Huamantinco and Nessimian, 2000; Buss et al., 2004), are equally abundant in rainfall or drought, and even more abundant during the latter. This may be explained because the disturbance has less of an effect on taxa adapted to frequent flooding conditions or with greater dispersal ability, who are the first to recolonize (Winemiller et al., 2010). The collector-filterers strategy is used normally by other taxa to avoid the limitations of rapid currents, or as those of Huleechius during rainy periods (Brown, 1981), as was found in the Guarinó River.

The trophic flexibility of Guarinó River macroinvertebrates confirms the results of a review by Covich (1988) and a study by Tomanova et al. (2006), which suggests that food webs in Neotropical mountain rivers are dominated by generalist consumers, who can occupy at least two trophic levels. In stable environments, such flexibility may reduce intraspecific competition (Woodward and Hildrew, 2002), but in environments with high hydrological disturbance regime and variability in the supply of autochthonous and allochthonous food resources, the ability 
to exploit changing resources can potentially maintain population stability to natural fluctuations (Hart and Robinson, 1990).

Although no information is available on the habit level response against the ENSO phenomena in other systems, the dominance of clinger habits, as was found in the Guarinó River, has been documented by Hanson et al. (2010) in areas of strong current. Clinger macroinvertebrates often show adaptations to grab or hold onto the substrate, corroborating adaptive strategies to frequent drag events (disturbances) in the Guarinó River. The presence of burrowers during El Niño is also evidence of an adaptive (buried) strategy in response to drought conditions.

\section{CONCLUSIONS}

In conclusion, the ENSO phenomena El Niño and La Niña had a great impact on the Guarinó River during 2007-2010, causing significant taxonomic and functional changes in macroinvertebrate assemblages. This response was based on the specific adaptations to natural hydrological disturbance on local habitat characteristics, according to predictions of the Habitat Templet Theory (Townsend and Hildrew, 1994). Our understanding of this relationship and its application to the management and recovery of aquatic ecosystems in the Andean foothills will help avoid errors due to the generalisation of response patterns of other systems. Differentiated results between rivers and regions also highlight the need for standardisation in the methods of collecting samples, which will allow for comparisons and more conclusive analyses.

\section{ACKNOWLEDGMENTS}

We thank the research group on Limnology and Water Resources of the Universidad Católica de Oriente for the human and technical support throughout the process, the Laboratory of Ecology and Management of Estuaries and Aquatic Ecosystems of the Federal University of Pernambuco and Laboratory of Ecology and Conservation of Wildlife of the National University of Colombia for their academic support, MSc Professor Patricia Pelayo for his support in the statistical analysis and especially the company ISAGEN S.A. E.S.P. and the Universidad Católica de Oriente, which co-financed this research. We appreciate the support of the Curricular Area in Forest and Environmental Conservation Faculty of Agricultural Sciences, Universidad Nacional de Colombia, for its support in correcting the style and English text.

\section{REFERENCES}

Aguirre-Pabón J, Rodríguez-Barrios J, Ospina-Torres R, 2012. [Deriva de macroinvertebrados acuáticos en dos sitios con diferente grado de perturbación, río Gaira, Santa Marta Colombia].[Article in Spanish]. Rev. Intropica 7:9-19.
Allan JD, 1996. Stream ecology. Structure and function of running waters. Chapman \& Hall, New York: 338 pp.

Álvarez LF, 1982. [Estudio del orden Hemíptera (Heteróptera) en el Departamento de Antioquia en diferentes pisos altitudinales]. [PhD Thesis in Spanish]. Universidad de Antioquia, Medellín.

Álvarez LF, 2005. [Desarrollo de una metodología para la evaluación de los macroinvertebrados acuáticos como indicadores de los recursos hidrobiológicos].[In spanish]. Contrato $\mathrm{N}^{\circ} 05$ 01-24843-0424PS, Instituto de Investigación de Recursos Biológicos "Alexander von Humboldt", Bogotà.

Álvarez LF, Arango MC, Roldán G, 2006. [Diversidad de los macroinvertebrados dulceacuícolas en Colombia], p. 261287. In: [Informe nacional sobre el avance en el conocimiento y la información de la biodiversidad 19982004].[Book in Spanish]. Arfo Editores e Impresores Ltda.

Amaya A, 2008. [Colonización de sustratos artificiales por macroinvertebrados: influencia de las variables hidrológicas]. In: [Ecología de un río de montaña de los Andes colombianos (Río Tota, Boyacá)].[Book in Spanish]. Universidad Nacional de Colombia.

APHA, AWWA, WEF, 2005. Standard methods for the examination of water and wastewater, 21st ed. American Public Health Association, American Water Works Association and Water Environment Federation. Washington.

Arango MC, 1983. [Estudio de los odonatos inmaduros del Departamento de Antioquia].[PhD Thesis in Spanish]. Universidad de Antioquia, Medellín.

Aristizábal H, 2002. [Los hemípteros de la película superficial del agua en Colombia. Parte I: Familia Gerridae].[Book in Spanish]. Colección Jorge Álvarez Lleras N. 20, Rev. Acad. Colomb. Cienc.: 240 pp.

Bedoya I, 1984. [Estudio de los dípteros acuáticos (Diptera) en diferentes pisos altitudinales en el Departamento de Antioquia].[PhD Thesis in Spanish]. Universidad de Antioquia, Medellín.

Biggs BJF, Nikora VI, Snelder TH, 2005. Linking scales of flow variability to lotic ecosystem structure and function. River. Res. Appl. 21:283-298.

Biggs BJF, Tuchman NC, Lowe RL, Stevenson RJ, 1999. Resource stress alters hydrological disturbance effects in a stream periphyton community. Oikos 85:95-108.

Blanchette ML, Pearson RG, 2012. Dynamics of habitats and macroinvertebrate assemblages in rivers of the Australian dry tropics. Freshwater Biol. 58:742-757.

Blanco JF, 2003. Interannual variation of macroinvertebrate assemblages in a dry-forested stream in western Cordellera: a role for El Niño and La Niña? Bol. Ecotropica 37:3-30.

Borrero C, 2010. [Componente geológico y amenazas naturales del POMA Río Guarinó]. Documento técnico: Plan de ordenación y manejo de la cuenca hidrográfica mayor del río Guarinó [In Spanish].CORPOCALDAS 2010.

Boulton AJ, Peterson CG, Grimm NB, Stuart G, Fisher G, 2013. Stability of an aquatic macroinvertebrate community in a multiyear hydrologic disturbance regime. Ecology 73:2192-2207.

Brown HP, 1981. Huleechius, anew genus of riffle beetle from Mexico and Arizona (Coleoptera, Dryopoidea, Elmidae). Pan-Pac Entomol. 57:228-244.

Buss DF, Baptista DF, Nessimian JL, Egle RM, 2004. Substrate specificity, environmental degradation and disturbance 
structuring macroinvertebrate assemblages in neotropical streams. Hydrobiologia 518:179-188.

Castro MI, Donato JC, 2008. [Patrones generales de emergencia de macroinvertebrados]. In: [Ecología de un río de montaña de los Andes Colombianos (Río Tota, Boyacá)].[Book in Spanish]. Universidad Nacional de Colombia.

Chará AM, Chara JD, Zúñiga M, Pedraza GX, Giraldo LP, 2010. [Clasificación trófica de insectos acuáticos en ocho quebradas protegidas de la ecorregión cafetera colombiana].[Article in Spanish]. U. Scient. 15:27-36.

Cobo F, González M, 1990. [Las comunidades de Quironómidos (Diptera: Chironomidae) del Río Ulla (NW de España)].[Article in Spanish]. Limnetica 6:109-118.

Collier KJ, 2008. Temporal patterns in the stability, persistence and condition of stream macroinvertebrate communities: relationships with catchment land-use and regional climate. Freshwater Biol. 53:603-616.

Correa M, 1980. [Taxonomía y ecología del orden Trichoptera en el Departamento de Antioquia en diferentes pisos altitudinales].[PhD Thesis in Spanish]. Universidad de Antioquia, Medellín.

Covich AP, 1988. Geographical and historical comparisons of Neotropical stream-biotic diversity and detrital processing highly variable habitats. J. N. Am. Benthol. Soc. 7:361-386.

Cressa C, 1998. Community composition and structure of macroinvertebrates of the river Camurí Grande, Venezuela. Verh. Internat. Verein. Limnol. 26:1008-1011.

Domínguez E, Hubbard MD, Peters W, 1992. [Claves para ninfas y adultos de las familias y géneros de Ephemeroptera (Insecta) sudamericanos].[Book in Spanish]. Biología Acuática No. 16. Inst. Limnol. Dr. Raúl A. Ringuelet: 38 pp.

Domínguez E, Hubbard MD, Pescador ML, 1994. [Los Ephemeroptera en Argentina].[Book in Spanish]. Fauna de agua dulce de la República de Argentina 33:1-142.

Dudgeon D, 1993. The effect of spate-induced disturbance, predation and environmental complexity on macroinvertebrates in a tropical stream. Freshwater Biol. 30:189-198.

Edmonson WT, 1959. Freshwater biology. 2. John Wiley \& Sons: $1248 \mathrm{pp}$.

Edmunds GF, 1976. The mayflies of North and Central America, University of Minnesota Press, Minneapolis: 329 p.

Flecker AS, Feifarek B, 1994. Disturbance and the temporal variability of invertebrate assemblages in two Andean streams. Freshwater Biol. 31:131-142.

Gauch HG, 1982. Multivariate analysis in community ecology. Cambridge University Press: 298 pp.

Gilbert B, Dillon PJ, Somers KM, Reid RA, Scott L, 2008. Response of benthic macroinvertebrate communities to El Niño related drought events in six upland streams in south-central Ontario. Can. J. Fish Aquat. Sci. 65:890-905.

Grimm NB, Fisher SG, 1989. Stability of periphyton and macroinvertebrates to disturbance by flash floods in a desert stream. J. N. Am. Benthol. Soc. 8:293-307.

Guisande C, 2015. StatR. Available from: http://www.ipez.es/ RWizard

Gutiérrez JD, 2006. [Caracterización del metabolismo y de la oferta de recursos de materia orgánica para la fauna de macroinvertebrados bentónicos en una quebrada de montaña de orden menor].[PhD Thesis in Spanish]. Universidad Nacional de Colombia, Bogotá.
Hanson P, Springer M, Ramírez A, 2010. [Introducción a los grupos de macroinvertebrados acuáticos].[Article in Spanish]. Rev. Biol. Trop. 58(Suppl. 4):3-37.

Hart DD, Robinson CT, 1990. Resource limitation in a stream community: phosphorus enrichment effects on periphyton and grazers. Ecology 71:1494-1502.

Hendricks AC, Willis LD, Snyder C, 1995. Impact of flooding on the densities of selected aquatic insects. Hydrobiologia 299:241-247.

Holdridge LR, 1982.[Ecología basada en zonas de vida].[Book in Spanish]. IICA, San José: 215 pp.

Huamantinco AA, Nessimian JL, 2000. Variation and life strategies of the Trichoptera (Insecta) larvae community in a first order tributary of the Paquequer River, southeastern Brazil. Rev. Brasil. Biol. 60:73-82.

Hungerford HB, Matsuda R, 1960. Keys to subfamilies, tribes, genera and subgenera of the Gerridae of the world. University of Kansas: 632 pp.

Hynes JD, 1975: Annual cycles of macro-invertebrates in a river in southern Ghana. Freshwater Biol. 5:71-83.

IDEAM - Instituto de Hidrología, Meteorología y Estudios Ambientales, 2012. [Boletín informativo sobre el monitoreo del fenómeno de "El Niño"].[In Spanish]. Oficina del Servicio de Pronósticos y Alertas República de Colombia. Available from: http://www.pronosticosyalertas.gov.co/jsp/boletin-informativo-sobre-el-monitoreo-de-los-fenomenos-de-elnino-y-la-nina 894

Jacobsen D, 2005. Temporally variable macroinvertebrate-stone relationships in streams. Hydrobiologia 544:201-214.

Jacobsen D, 2008. Tropical high-altitude streams, p. 219-256. In: D. Dudgeon (ed.), Tropical stream ecology. Elsevier Inc. Academic Press, San Diego.

Jacobsen D, Encalada A, 1998. The macroinvertebrate fauna of Ecuadorian high-land streams in the wet and dry season. Arch. Hydrobiol. 142 53-70.

Lake PS, 2000. Disturbance, patchiness, and diversity in streams. J. N. Am. Benthol. Soc. 19:573-592.

Longo M, Zamora H, Guisande C, Ramirez JJ, 2010. [Dinámica de la comunidad de macroinvertebrados en la quebrada Potrerillos (Colombia): Respuesta a los cambios estacionales de caudal].[Article in Spanish]. Limnetica 29:195-210.

Machado T, 1989. [Distribución ecológica e identificación de los coleópteros acuáticos en diferentes pisos altitudinales del Departamento de Antioquia].[PhD Thesis in Spanish]. Universidad de Antioquia, Medellín.

Manzo V, 2005. Key to the South America genera of Elmidae (Insecta: Coleoptera) with distributional data. Stud. Neotrop. Fauna E. 40:201-208.

Mathuriau C, Thomas-Alain GB, Chauvet E, 2008. Seasonal dynamics of benthic detritus and associated macroinvertebrate communities in a neotropical stream. Fund. Appl. Limnol.Arch. Hydrobiol. 171:323-333.

Mazzucconi S, López M, Bachmann A, 2009. [Hemiptera-Heteroptera: Gerromorpha y Nepomorpha], p. 167-231. In: [Macroinvertebrados Bentónicos Sudamericanos. Sistemática y Biología].[Book in Spanish]. Fundación Miguel Lillo, Tucumán.

McCafferty WP, 1981. Aquatic Entomology. Science Books Int., Boston: 448 pp.

Melo SA, Froehlich CG, 2001. Macroinvertebrates in neotropi- 
cal streams: richness patterns along a catchment and assemblage structure between 2 seasons. J. N. Am. Benthol. Soc. 20:1-16.

Merritt RW, Cummins KW, 1996. An introduction to the aquatic insects of North America. $3^{\text {rd }}$ ed. Kendall/Hunt, Dubuque: $862 \mathrm{pp}$.

Molles MC, Dahm Jr. CN, 1990. A Perspective on El Niño and La Niña: global implications for stream ecology. J. N. Am. Benthol. Soc. 9:68-76.

NOAA-National Oceanic and Atmosferic Administration, CIRES-Climate Diagnostic Center. 2012 "Multivariate ENSO index (MEI)". Available from: http://www.esrl.noaa. gov/psd/enso/mei/index.html

NOAA-National Oceanic and Atmosferic Administration, NCEP-Climate Prediction Center. 2014. ENSO: Recent evolution, current status and predictions. Updated 14-04-2014.

Posada JA, Roldán G, Ramírez JJ, 2000. [Caracterización fisicoquímica y biológica de la calidad de aguas de la cuenca de la quebrada Piedras Blancas, Antioquia, Colombia].[Article in Spanish]. Rev. Biol. Trop. 48: 59-70.

Posada JA, Roldán G, 2003. [Clave ilustrada y diversidad de las larvas de Trichoptera en el Nor-occidente de Colombia].[Article in Spanish]. Caldasia 25:169-192.

Quinn GP, Keough MJ, 2002. Experimental design and data analysis for biologist. Cambridge University Press: 537 pp.

Ramírez A, Gutiérrez-Fonseca PE, 2014. Functional feeding groups of aquatic insect families in Latin America: a critical analysis and review of existing literature. Rev. Biol. Trop. 62(Suppl. 2):155-167.

Ramírez A, Pringle CM, 1998. Structure and production of a benthic insect assemblage in a neotropical stream. J. N. Am. Benthol. Soc. 17:443-463.

Ribeiro OL, Uieda SV, 2005. [Estrutura da comunidade de macroinvertebrados bentónicos de um riacho de serra em Itatinga, São Paulo, Brasil].[Article in Portuguese].Ver. Bras. Zool. 22:613-618.

Ríos-Pulgarín MI, Barletta M, Mancera-Rodríguez NJ, 2015. The role of hydrological cycle on the patterns of the fish assemblage distribution in an Andean stream. J. Fish Biol. doi: 10.1111/jfb.12757. [Epub ahead of print].

Ríos-Touma B, Encalada AC, Prat-Fornells N, 2009. Leaf litter dynamics and its use by invertebrates in a high-altitude tropical Andean stream. Int. Rev. Hydrobiol. 94:357-351.

Ríos-Touma B, Encalada AC, Prat-Fornells N, 2011. Macroinvertebrate assemblages of an Andean high-altitude tropical stream: the importance of season and flow. Int. Rev. Hydrobiol. 96:667-685.

Ríos-Touma B, Prat N, Encalada A, 2012. Invertebrate drift and colonization processes in a tropical Andean stream. Aquat. Biol. 14:233-246.

Rodríguez-Barrios JA, Ospina-Torres R, Gutierrez JD, Ovalle H,
2007. [Densidad y biomasa de macroinvertebrados acuáticos derivantes en una quebrada tropical de montaña (Bogotá, Colombia)].[Article in Spanish]. Caldasia 29:397-412.

Rodríguez-Barrios JA, Ospina-Tórres R, Turizo-Correa R, 2011. [Grupos funcionales alimentarios de macroinvertebrados acuáticos en el río Gaira, Colombia].[Article in Spanish]. Rev. Biol. Trop. 59:1537-1552.

Roldán G, 1988. [Guía para el estudio de los macroinvertebrados acuáticos del departamento de Antioquia].[Book in Spanish]. Fondo FEN- Colombia. Edit. Presencia, Bogotá: 217 pp.

Roldán G, Ramírez JJ, 2008. [Fundamentos de Limnología neotropical]. 2. [Book in Spanish]. Editorial Universidad de Antioquia, Medellín.

Southwood TRE, 1977. Habitat, the templet for ecological strategies. J. Anim. Ecol. 46:337-365.

Scarsbrook MR, McBride CG, McBride GB, Bryers GG, 2003. Effects of climate variability on rivers: consequences for long term water quality. J. Am. Water Resour. As. 39:1435-1447.

Spangler PJ, Santiago S, 1992. The aquatic beetle subfamily Larainae (Coleoptera: Elmidae) in Mexico, Central America, and the West Indies. Smithsonian Institution Press: 74 pp.

Swanson FJ, Johnson SL, Gregory SV, Acker SA, 1998. Flood disturbance in a forested mountain landscape. BioScience 48:681-689.

Tomanova S, 2007. Functional aspect of macroinvertebrate communities in tropical and temperate running waters. $\mathrm{PhD}$ Thesis, Brno University of Technology.

Tomanova S, Goitia E, Helesic J, 2006. Trophic levels and functional feeding groups of macroinvertebrates in neotropical streams. Hydrobiologia 556:251-264.

Tomanova S, Usseglio-Polatera P, 2007. Patterns of benthic community traits in Neotropical streams: relationship to mesoscale spatial variability. Fund. Appl. Limnol. 170:243-255.

Townsend CR, 1989. The patch dynamics concept of stream community ecology. J. N. Am. Benthol. Soc. 8:36-50.

Townsend CR, Hildrew AG, 1994. Taxonomic traits in relation to a habitat templet for river systems. Freshwater Biol. 31: 265-275.

Wang X, Caia Q, Jianga W, Qua X, 2013. Interannual patterns in the stability and persistence of stream macroinvertebrate communities: relationship with water physicochemical parameters. J. Freshwater Ecol. 28:79-90.

Wiggins GB, 1977. Larvae of the North American caddisfly genera (Trichoptera). University of Toronto Press: 401 p.

Winemiller KO, Flecker A, Hoeinghaus DJ, 2010. Patch dynamics and environmental heterogeneity in lotic ecosystems. J. N. Am. Benthol. Soc. 29:84-99

Woodward G, Hildrew AG, 2002. Body-size determinants of niche overlap and intraguild predation within a complex food web. J. Anim. Ecol. 71:1063-1074. 